\title{
After Liberal Peace? From Failed State-Building to an Emancipatory Peace in Kosovo
}

DOI:

10.1093/isp/ekw006

Document Version

Accepted author manuscript

Link to publication record in Manchester Research Explorer

\section{Citation for published version (APA):}

VISOKA, GEZIM., \& Richmond, O. (2016). After Liberal Peace? From Failed State-Building to an Emancipatory Peace in Kosovo. International Studies Perspectives. https://doi.org/10.1093/isp/ekw006

\section{Published in:}

International Studies Perspectives

\section{Citing this paper}

Please note that where the full-text provided on Manchester Research Explorer is the Author Accepted Manuscript or Proof version this may differ from the final Published version. If citing, it is advised that you check and use the publisher's definitive version.

\section{General rights}

Copyright and moral rights for the publications made accessible in the Research Explorer are retained by the authors and/or other copyright owners and it is a condition of accessing publications that users recognise and abide by the legal requirements associated with these rights.

\section{Takedown policy}

If you believe that this document breaches copyright please refer to the University of Manchester's Takedown Procedures [http://man.ac.uk/04Y6Bo] or contact uml.scholarlycommunications@manchester.ac.uk providing relevant details, so we can investigate your claim.

\section{OPEN ACCESS}




\title{
After Liberal Peace? \\ From Failed Statebuilding to an Emancipatory Peace in Kosovo
}

\author{
GËZIM VISOKA \\ Dublin City University \\ OLIVER RICHMOND \\ University of Manchester
}

\begin{abstract}
Attempts to build a liberal peace and a concurrent neoliberal state in Kosovo have not managed to produce a sustainable and emancipatory peace. Instead, they have produced a local and negative hybrid peace that has been co-opted by the dynamics of local state formation and state contestation. These dynamics have overshadowed a meaningful transition from ethnic hostility to sustainable peace, which in Kosovo's context encompasses pluralism, security, law, rights, and liberal institutions, as well as the recognition of contextual identity and historical political struggles for justice. This article examines the emergence of a negative hybrid peace and explores the prospects for a more emancipatory form of peace based on local pro-peace infrastructure which avoids the pitfalls of liberal peace in practice.
\end{abstract}

Keywords: Liberal peace, failed statebuilding, hybrid peace, emancipatory peace, Kosovo.

To date, liberal peace and its awkward relative, the neoliberal state, have been the dominant conceptual and policy frameworks that have guided contemporary peacebuilding and later statebuilding work in post-conflict societies. Due to their inherently interventionist nature and desire for stability and control, international actors through liberal peacebuilding and neoliberal statebuilding have tried to re-engineer post-conflict societies by applying political and economic models that have not always been suited to the local context, culture, and the democratic will of the local people (Newman, Paris and Richmond 2009). Liberal peace has given priority to translating external needs into internal rights-oriented obligations, while challenging internal identities and needs by imposing regimes connected to rights and capital. This appears to avoid the need for complex diplomacy or social reconciliation, and has certainly had significant impact in Kosovo and across the Balkans. Consequently, asymmetric power-relations on the ground and in the region, the imposition of an alien or only thinly universal political, economic and social system, unaccountable authority and interventionary practices, and the externally led disciplining of local society and employees by western- 
dominated states, organizations and NGOs have left post-conflict societies exposed to unpredictable consequences, failures and anomalies (Richmond 2005; Chandler 2009). The emancipatory aspects of liberal peace, such as rights, justice and reconciliation, and their expected materialisation into a higher living standards, have mainly appeared as justification for interventionary policies, and have their progressive intent has vanished in practice.

From the perspective of the peace community in Kosovo, as well as from many critical scholars, negative mutations of hybrid peace are not emancipatory as they are rooted in exclusionary practices and inequality. Negative hybrid peace is defined as "rigorously determined liberal institutionalism and market development solutions with patriarchal, feudal, communal, or sexist, practices" (Richmond 2011, 18; 2015). A quest for more post-liberal, emancipatory forms of peace is immanent to overcome ethno-nationalist dynamics, semiauthoritarian elite predation, and negative effects of external intervention. This article argues that for a localized emancipatory peace to emerge it should be rooted in dialogic commitments of local and international actors and reformed state institutions. This would ensure more inclusive democracy and find conciliatory modalities on the divisive issues of identity, sovereignty, territoriality, culture, citizenship, and political representation. This would represent a hybrid mix of both international and local political projects in Kosovo, given its recent history. Such an argument reflects the views of those actors involved in peacebuilding at local levels, and those who have had experience working with regional and international actors, and appears to confirm some of the arguments in the critical literature in international relations (Richmond 2009). However, this represents only a small group of liberal, critical, and progressive thinkers, raising the question of how it might be more broadly encouraged. In this article, we chart some of the conceptual and empirical aspects of this putative emancipatory peace as a derivative of peace formation after failed statebuilding in conflict-affected societies. The article assesses the current state of peace in Kosovo, drawing on extensive conversations and field research with local communities and comprehensive review of scholarly and policy research on Kosovo. It provides an empirical contribution to the emerging debates on post-liberal forms of peace by illustrating some of its contextual characteristics in Kosovo (see Richmond and Pogodda 2016).

The story of liberal peace in Kosovo is a story of parallel struggles between externally set peacebuilding and statebuilding, which was challenged by the dynamics of local state formation and state contestation. The international peacebuilding and statebuilding process in Kosovo temporarily interrupted and later substantiated Kosovo's state formation process within the somewhat contradictory limits set by liberal peacebuilding, European Union (EU) 
conditionality, and regional geopolitics (Capussela 2015; Visoka 2016a). The conflicting agendas of each of these aspects have undermined the peace process, leaving both external and local political agendas incomplete, fragmented, and subject to constant contestation. Under these conditions, the space for emancipatory peace was very limited and suppressed by internal and external geopolitical and structural forces. What has emerged from these conflicting agendas is a variety of unintended hybrid outcomes in the democratization and governance process, in managing ethnic relations, in building civil society and human rights regimes, in establishing the rule of law, and in reconstructing the economy (Richmond 2005, 198; 2014, 57). Nevertheless, certain local civil society groups in Kosovo provide some evidence of peace formation aimed at constructing locally legitimate peace frameworks, which are also for the most part connected to international liberal agendas. The negative hybrid peace that has emerged raises contentious issues between insider and outsider actors regarding the nature of peace, justice, reconciliation, state sovereignty, governance, security, and economy in Kosovo. These divisions are rooted in the legacies of the past, but also are products of failed statebuilding in Kosovo. The state has failed to meet the diverse claims of its populations, and has instead been framed according to a mixture of external blueprints and local elite preferences.

This article explores the space for a positive hybrid peace in Kosovo. Positive hybrid peace is defined as "complementary practices related to democracy, self-determination, agency, autonomy, solidarity, human rights and needs, and a rule of law, with customary social support networks, customary forms of governance and political order" (Richmond 2011, 19). We combine critical qualitative and descriptive analysis with field research in Kosovo to explore the performance and impact of liberal peacebuilding as well as explore what an emancipatory peace would look like in Kosovo. We depart from existing liberal peace accounts by suggesting peace enablement rather than external intervention, and greater attention to local agencies for peace formation than empowerment of ethno-nationalist peacebreakers. We argue that the failure of liberal peace to produce a positive peace in Kosovo should not be seen as the end of the critique, rather a necessary departure for exploring alternatives to the emergent negative peace in the country. To make the case for an emancipatory peace, it is important to explore social conditions shaping peace in Kosovo and critically engage with the potentials for emancipatory transformation.

We argue that an "ideal state" (Trindade 2008) for Kosovo would require a new locally-formed and externally-enabled peace arrangement, which is not rooted on the basis of ethno-nationalism but on plural identities, an inclusive type of statehood, institutions, and 
services, as well as a formal peace with Serbia. It would also require significant security and material support from the UN, donors, and the EU. Broad self-governance for minorities would be necessary, as well as a governance model that emancipates and empowers citizens while alleviating social inequalities. While some of these aspects were advocated by liberal peace proponents, the process and means for achieving them were unsuccessful. We depart from existing liberal peace frameworks as we do not advocate renewing externally imposed liberal peace frameworks, but rather locally generated emancipatory policies aimed at producing reconciliation, which engages as necessary with external liberal actors. In what follows, we outline the negative hybrid peace frameworks that have emerged during the local encounter with liberal peace missions in Kosovo, and then explore whether it provided the potential for a positive hybrid and therefore more emancipatory peace.

\section{An Emancipatory Peace after Liberal Peace?}

In the past two decades, liberal peace has guided scholarly debates and policy practices on post-conflict societies. Liberal peace entails addressing root causes of conflict through implanting democratic governance and economic liberalism through a broad range of interventionary practices (Paris 2010; Doyle 2012). The focus of liberal peacebuilding on constructing and reconstructing state institutions, writing laws and regulations, and setting enforcement mechanisms has contributed to the creation of negative hybrid forms of peace, which are a step forward from the past situation, but insufficient for a sustainable peace (see Tadjbakhsh 2011). In most societies, liberal peace frameworks have unintentionally produced an impasse for democracy and sustainable peace. Negative and positive gradations of hybrid peace are being used as a way to capture this combination of positive and negative political processes that combine elements of democratic practice, self-governance, solidarity and justice with more negative dynamics of external imposition and within-group ethnonationalist domination (see Richmond 2005, 198; Mac Ginty 2014). Jarstad and Belloni define hybridity as "a condition where liberal and illiberal norms, institutions, and actors coexist, interact, and even clash" $(2012,1)$.

In many cases, new peace processes and settlements are captured by ethno-nationalist exclusionary dynamics that do not foster reconciliation, justice, and emancipation. Peace disrupts existing power relations so it should not be surprising that power attempts to capture peace processes. Since the early 1990s, this has generally resulted in capitalist states that pay lip-service to human rights and democratic norms and processes. Seen from a normative perspective, one of the most harmful dimensions of negative hybrid peace is exclusionary 
ethnic politics. Although high-level peace agreements might hold, peaceful communities cannot emerge through a social contract imposed from outside and through elite pseudorepresentative politics (Jarstad and Sisk 2008). In such cases, power is encapsulated by a small elite, which draws on both majority and minority communities that capture moderate political voices and blocks cross-community cleavages. Such authoritarian dynamics are a product of international community's reliance on and exploitation of a small political elite who are capable of maintaining domestic stability in exchange for securing external legitimacy at the expense of ignoring other pro-peace social groups.

Universalist notions of peace have proven not to be fit for purpose in various particularistic contexts (Mac Ginty 2014). Prioritizing security and top-down statebuilding has overshadowed moral necessity for engagement, representation and autonomy in postconflict societies. Peace embedded in ethnic politics has created minorities within minorities, and endless cycles of domination and revenge. Neoliberal statist frameworks have impeded reconciliation and emancipation. The urge for a new social contract is critical in many postconflict societies. The negative hybrid peace that has emerged in conflict-affected societies should not be seen as an acceptable state of affairs or end result of failed statebuilding and peacebuilding. The role of critical approaches should be to move beyond negative hybrid peace, otherwise accepting negative hybrid peace as the end result of a peace process would mean accepting structural inequalities and latent tensions that pertain to conflict-affected societies. In fact, the very idea of hybrid peace has been to describe the transitory stage towards a more positive, durable peace if social preferences can be recognized and mediated and legitimate authority, plus a capacity to intervene, constructed accordingly. One potential avenue is to search for emancipatory forms of peace inside and outside the state framework and norms of liberal peace. In this context, an emancipatory peace should be understood as a transformative process after negative hybrid peace, whereby a positive hybrid peace emerges and overcomes structural and agential impediments to create space for local emancipation, justice, and equality and co-existence with regional and international structures. Such postliberal forms of peace (see Richmond 2011; Richmond 2014) radically displace the potential for peace formation from external interveners to internal peace formers.

The concept of an emancipatory peace is linked to long standing debates in political theory and philosophy about the nature of emancipation and progress, as well as the role of progress in leading to the good life for society, often in democracies (Richmond 2008). Progress is often associated with liberalism and modernity, and has been subject to extensive criticism (Giddens 1991). From a social and liberal perspective, since the $19^{\text {th }}$ Century 


\section{After Liberal Peace?}

progress represented security and the improvement of rights pertaining to life, work, and welfare. More recently, progress has become connected with legal equality, sustainable economies and ecologies, an approximation of material equality, networks and mobility (Balibar 2002). This latter perspective, offering a version of emancipation for the contemporary era, provides a different understanding of the desired peace, where progress is related to contingent, and non-determinist transformation (see Susen 2015, 156). Emancipatory peace is not a mere reproduction of liberal peace: rather it signifies localized efforts for forming peace by peaceful means, autonomous from elite predation and external intervention, but able to draw upon external support where necessary to prevent conflict actors from establishing blockages to peace, for security, resources, knowledge, and accountability. It enables citizens to improve their rights, material conditions, access to public services, security, and maintain identity where necessary. This represents a post-liberal form of peace, which implies that locally legitimate authorities and peace enablers would work with external forces against obstacles to peace, whether structural or political, in postcolonial, pluriversal, empathetic and emancipatory terms.

While classical progressivists believe in predictable patterns of historical and social progression (Locke 1988 [1689]), the idea of emancipatory peace indicates a less predetermined or vanguardist progressivism, which nevertheless can take place if certain enabling local and international conditions exist. It requires an updated understanding of emancipation and social justice, as well as the local, state, regional, and international, transversal and transnational actors or networks that might facilitate it. In this context, the notion of emancipation is deeply rooted in local legitimacy and bottom-up solutions, as well as in the role of the state, regional organisation, and international law and institutions, at least in modern history. Emancipatory peace entails a pluraliversal - meaning for all involved parties - conception of peace across global scales and networks, designed locally and contextually to deal with legal, material, political and social inequalities and obstacles. Unlike liberal peace, emancipatory peace requires a more critical, yet pluralist citizenry that would overcome local ethno-nationalist identity, and power-ridden authoritarian elites, patriarchy, and social discrimination, and who would promote local and bottom-up alternatives to governance that are neither harmful nor suppressive to any social group.

While liberal peace has discursively supported progressive processes through institutionalisation and civil society building, concerns with stability have accommodated ethno-nationalist groups and ignored other local potentials for peace. Normative frameworks of liberal peace are co-opted by neo-liberal statebuilding and local authoritarian tendencies. 
Thus we need to go beyond these entrapments and focus on the everyday, people-centred approaches to peacebuilding. Rethinking the role of people in society and enabling their agency is crucial as the space for change exists more among dynamic subaltern agencies than through entrenched formal state structures: international engagement offers support but only if there is political will. As Linklater maintains, this is important "in shaping critical political cultures which are sensitive to the varieties of exclusion and open to progressive development" (1997, 334). He calls for "the enlargement of citizenship to embrace social and economic rights' through recognizing difference," and "modified to take account of the particular needs and interests of subaltern groups" (Linklater 1997, 335-336). Emancipatory peace would be more likely to produce results if it is settled on a mobile, post-Westphalian notion of citizenship, recognizing that citizens may have multiple loyalties and identities while remaining committed to the joint political and civic obligations of the political community, thus bypassing sovereignty entrapments.

Emancipatory peace rests on the conviction that local critical agency can drive progress and freedom, which are mutually constitutive and have the potential to reconstitute each other (see Brink 2013). Local emancipation requires equal opportunity for all identity groups to determine their own lives within the contours of contemporary political communities. As Rorty claims, progress entails expanding the "sense of solidarity" and to reach out to the "marginalized people - people whom we still instinctively think of as 'they' rather than "us"” $(1989,196)$. Emancipatory peace would offer "freedom from unjustifiable forms of exclusion" (Shapcott 2011, 86). As Booth states, "emancipation, not power or order, produces true security" (1991, 319). In our understanding, emancipatory peace requires postexclusionary politics, which are more sensitive to local communitarian needs than predetermined ethnic politics, but can be scaled up into pluralistic institutions, law, constitutions, international organisations and networks in a way that difference does not produce untenable contradictions for the ensuing systems of governance.

Hence, "a more locally determined balance between rights and needs may produce a hybrid form of peace in its own right" (Richmond 2015, 59). The fit between the local and the international is not homogenous, but instead agonistic and constantly pushing for mutual improvements. It requires ending social and economic inequality and not reproducing material subordination through neoliberal economic reforms, nor maintaining through the existing states-system long-standing injustices. Booth states that, "liberty is also the central value of emancipation, but emancipation implies an egalitarian concept of liberty" (1991, 321-322). Accordingly, peaceful and non-violent pathways in post-conflict societies require 
the formation of "dialogic communities." According to Linklater, their primary role is to "transcend unjust exclusion," which has local, state, and global dynamics $(1998,50)$. This dialogical process should result in achieving everyday "reflective equilibriums," which according to Rawls entail temporary adjustment of principles and considered judgments $(1971,18)$. In this sense, affiliated notions with liberal peace, such as social contract, rights, civility, and security need to be decolonized, and instead explore them in their contextual sense, not only taken for granted as universal blueprints.

Thus far, liberal peacebuilding has failed to create dialogical communities because it has focused on existing power-structures rather than social potential, and so has invested extensively in "undeliberative" institutions and elitist civil society groups. The international civilian and military interventions have provided basic security; however, they have failed to promote an active and critical citizenry, which could be crucial to escape state capture by predatory elites. Critical and active citizenship is often manifested by concerned citizens through democratic, public and non-violent means to hold the government accountable and demand democratic governance (see Norris 2011). Dialogic communities would emerge from localized deliberations occurring on an organized or ad hoc basis at the community level not only as façade consultation but also as meaningful processes of local power sharing. Listening for peace is as important as preaching peace (see Dobson 2014). A more emancipatory peace would require changing the logic of international engagement, from one that is based on conditionality and intervention to a new mode of engagement, which is more conducive to and supportive of localized initiatives and dynamics of emancipation. The logic of peace should be enablement rather than non-consensual intervention. While intervention signifies imposition, enablement signifies facilitation. Peace enablement requires changing the international institutional guidelines for defining peace, practices for supporting peace efforts, and metrics for measuring success and impact. Recognizing local needs, rights, perspectives, identity, cultures, and practices would enable the negotiation of difference and reconciliation of local, state and international norms to ensure democratic legitimacy. An emancipatory peace by encouraging pluraliversal agencies opens space for local peace enablers to play a stronger role and balance against ethno-nationalist suffocation of peace. International peace enablement would neither be used as a sophisticated form of hidden intervention nor as a complex form of preventing and governing risk, but rather as an ethical commitment to respecting values, rights, and needs that first and foremost promote dignified life (Richmond 2014). 
How viable would emancipatory peace be? Would it constitute a rebranding of liberal peace or a more genuine post-liberal form of peace? Linklater clearly states that "normative arguments...are incomplete without a parallel sociological account of how they can be realized in practice... and normative and sociological advances are incomplete without some reflection on practical possibilities" $(1998,10)$. While critical theory within international relations is widely criticized for being too abstract, critical accounts of peacebuilding are deeply rooted in empirical research and close observation of discourse and practices. Next, we will explore further some of the claims about negative hybrid peace and the potential for emancipatory peace in Kosovo. The protracted and extensive international intervention in Kosovo to establish a liberal peace, and the emergence of a negative hybrid peace, make it an illustrative case which deserves detailed attention.

\section{Negative Hybrid Peace in Kosovo}

The liberal peace agenda in Kosovo was intended to placate, if not resolve, the root causes of conflict between Albanians and Serbs through a complex process of peacebuilding and statebuilding measures, while sidelining temporary local state/nation formation and state contestation dynamics (Hehir 2010; Richmond 2014). The international community has invoked statebuilding to satisfy the Albanian majority in Kosovo, while utilising peacebuilding as a tool to accommodate Serbs and minorities, as well as highlighting the benefits of regional stability. Both peacebuilding and statebuilding in Kosovo are rooted in violence, ethno-nationalist identity, power, territoriality and materiality, and have become adept at operating within both parapolitics and formal politics. The incompatibility of these agendas has co-opted the liberal peace agenda, leading to negative and hybridized outcomes driven by local and regional conflicts, but more or less remaining within the parameters set by the liberal state. For this reason, key peacebuilding activities included engineering multiethnicity as part of Kosovo's collective identity, supporting local civil society, facilitating the return and reintegration of refugees, and fostering multi-level inter-ethnic dialogue (King and Mason 2006). This approach did little to resolve local claims for state formation and state preservation, which of course are connected to a mixture of historical claims about identity, territory, and the necessary role of the state as the vehicle of self-determination and the agent of social justice. Within the UN-led provisional institutions in Kosovo, Albanian political elites in Kosovo tried to exploit statebuilding for their own state formation project, which connected self-determination with identity and independence. Although the compliance and incentivising power of liberal peace dominates post-conflict institutions, local agency within 
institutional frameworks managed to produce more complex hybrid positive and unintended outcomes.

The institutional architecture of liberal peacebuilding in Kosovo has declined over the time. Initially, the United Nations Interim Administration Mission in Kosovo (UNMIK) led the liberal peace framework in Kosovo in close cooperation with the European Union (EU), Organization for Security and Cooperation in Europe (OSCE), and North Atlantic Treaty (NATO) peacekeepers, alongside wide networks of other foreign governmental and nongovernmental agencies. After Kosovo's independence in 2008, a new International Civilian Office (ICO) and the European Union Rule of Law Mission in Kosovo (EULEX) overshadowed the roles of UNMIK and OSCE in Kosovo. As Kosovo's institutions consolidated their competences, more covert international interventions become common. This is evident with the everyday diplomatic interventions in shaping government agenda, controlling judiciary reforms and the rule of law, overseeing economic reforms, and tackling security threats. The existing discourse of local ownership offers new modes of dependency. Since 2012, new forms of interventionism emerged in Kosovo, led by foreign diplomatic circles. Publically, intervention is denied but under the surface there is a complex technology of domestic micro-management of political decisions, followed by conditionality and threats to withdraw support (US Department of State 2010; Capussela 2015). The international discourse that Kosovars need to take greater responsibility is nothing but a new mode of control through political judgement and conditionality, which reinforces local inferiority towards external actors (European Commission 2015).

The democratization and governance process in Kosovo has evolved in unintentional and unexpected directions. The compromise strategy of ethnic power-sharing promoted elitist representation and thus rendered citizen participation peripheral. Agenda setting was a topdown process that did not take popular, pro-peace opinion into consideration but aimed at maintaining stability through ethno-nationalist appeals: the fewer diverse claims involved, the easier it was to control the situation. For example, UNMIK proactively discouraged a referendum as a form of democratic deliberation, it discouraged participatory democracy and avoided public consultation for major political decisions or law-making processes during the transition. These illiberal practices of liberal peace were transmitted to the newly established local law enforcement institutions, which continued in the similar trajectory, but added a clanbased culture of governance hidden behind the appearance of a modern state (Anderson 2010). 
Mainstream liberal measurements of democracy in Kosovo show mixed results. The electoral turn out has constantly dropped (Central Election Commission 2014), and while trust in institutions has varied, it is generally low (UNDP 2015). Party politics have remained influenced by the nationalist agendas and there are almost no cross-ethnicity political constituencies. This situation preserves divided cleavages, distrust, allegiances, and political agenda, which often run against the agenda propagated by liberal peacebuilders in Kosovo. In the midst of this shallow democratic performance, international governance has not set positive examples in terms of its democratic conduct, evidenced by unaccountable practices and superficial involvement of local actors and affected communities in making and implementing policies. During the transition, the international community favoured working with a handful local power-holders and implemented its agenda through them (Tansey 2009). This has inevitably encouraged authoritarian practices within political parties and made external legitimacy more important than local legitimacy. This complex entanglement of power and legitimacy reduces opportunities for positive social change, increases nepotism and patronage relations, and suppresses any critical voice that seeks to challenge this figuration of power (Forum 2015 2011). Liberal peace tolerated these power relations in exchange for securing the compliance and stability of these local power-holders, following its widespread tendency to favour power-sharing and thereby support authoritarian and predatory capitalism and governance in tandem (Phillips, 2012). The power-sharing nature of politics in Kosovo contributed to "power-holding," which conveniently served international actors who wanted strong and predictable local leadership to enforce their agenda, and unintentionally enabled local actors to preserve power. Ultimately, recycling the same political elite narrowed the space for progress within institutional politics in Kosovo, and ignoring grassroots peace infrastructure reduced the scope for bottom-up peace formation.

One of the major areas of liberal peace in Kosovo has been the transformation of ethnic relations. While there have been constant attempts to provide incentives for ethnic communities to change their hostile relations, most efforts focused on working at the institutional level and with dominant ethnic leaders (King and Mason 2006). Over the years, ethnic crimes and confrontation decreased, but the overall hostile cross-community perceptions remain. Rooted in ethnic politics, minority representation mechanisms have played a limited role in peacebuilding, and served mainly as institutional battlefields for advancing ethnic agendas, benefiting materially from donations, generating in-group political support, and sustaining their political power and status (Visoka and Beha 2011). Despite the available transitional justice mechanisms, both UNMIK and local elites were reluctant to 
address human rights abuses and war crimes, which occurred during and after the war (OSCE 2010, 6). The ethno-politics of remembrance excluded other victims of the conflict, such as civilian victims, including minorities and women who suffered from sexual violence. The period of supervised independence after 2008 enabled the emergence of a moderate Serb political elite within Kosovo, which was part of government and successfully cooperated in forming new Serb municipalities and increasing socio-economic benefits for Serbs living across Kosovo, except in the north (KIPRED 2010). Their constructive approach towards the Kosovo state has contributed significantly in improving relations between Serbs and Albanians (International Crisis Group 2009). However, as the state required an end to Serbia's interference from the north of Kosovo in 2011, the space for moderate Serb politics vanished. The normalization of relations between Kosovo and Serbia has contributed to easing relations at the state level, but this has come at the expense of weakening the constituency for moderate Serb parties in favour of new nationalist factions (Srpska Lista) that are directly controlled and supported by Belgrade (Malazogu, Ejdus, Mič, and Żornaczuk 2014).

The rule of law and justice sector has been a major issue consuming the attention of liberal peace missions in Kosovo. The presence of multiple sources of applicable law, and the presence of local and international judges, prosecutors, and police officers did not create an effective rule of law environment in Kosovo. As the international missions reduced their presence, local judges became more vulnerable to political interference and failed to administer justice appropriately. The presence of EULEX in Kosovo has neither improved the rule of law, nor reduced corruption and abuse of power (Radin 2014). While police reform was hailed a success, the judiciary remains fragile. Consequently, corruption and organized crime endure and undermine efforts to establish a society based on the rule of law (Hehir 2010). The new justice system continues to be divided on an ethnic basis and signals of sustainability and self-reliance are not yet strong enough. Although there is a well-established legal and institutional framework for the protection of human rights in Kosovo, insufficient enforcement and numerous other constraints have resulted in disregarding universal entitlements to human rights and freedoms (OSCE 2009, 6; Ombudsperson in Kosovo 2012). From its inception, transitional justice in Kosovo has been a blurred process, where a thin line divided justice, nationalism, and mutual delegitimization between local and international actors (Kostovicova 2013). Currently, what stands in the way of improving the judiciary in Kosovo is the absence of institutional independence from political interference, the presence 
of corruption and sabotage, and the infiltration of clan-based networks within the justice system (International Crisis Group 2010).

The economic situation is another major and enduring problem. Kosovo remains the poorest country in Europe despite slow growth and fiscal stability. Unemployment remains high, around 30\% (KAS 2013). The international community has rushed to establish a neoliberal economy in Kosovo. The European Union and UNMIK wanted to complete a statebuilding process and define Kosovo's political status quickly in order to create the environment for undertaking full-scale neo-liberal reforms (Ruecker 2011, 18). Despite modest macroeconomic stability, the economy is highly dependent on financial and technical assistance from the international community and diaspora (Forum for Democratic Initiatives 2009). Informality has emerged as a response to the unfavourable neo-liberal economic system installed in Kosovo, which prioritizes rights, institutions, and rules above people's needs, welfare, and social security. The privatization process has significantly affected the collective organization of workers, whereby trade unions are not considered viable alternatives for private owners (Knudsen 2013).

High unemployment represents the main concern for Kosovo society, encouraging mass migration, informal economy, and social inequality (KAS 2013). The recent wave of illegal migration of Kosovo citizens to the European Union has pushed it and the Kosovo government to prioritize economic reforms and generate employment (Xharra 2015). Paradoxically, the European Union has been in charge of reconstructing Kosovo's economy and later in strengthening the rule of law, for which they have often praised themselves for achieving their intended goals. Nevertheless, in reality they helped to create something they now find insufficient and incompatible with European standards of governance. For several years, the European Union's annual progress reports on Kosovo documented the deficits and difficulties that Kosovo continuously faces to match the requirements of European Union membership, claiming that "the rule of law in Kosovo, including judicial independence, and limited results in the fight against organized crime and corruption remains a major concern" (European Commission 2014, 1). Unfortunately, the Kosovo case indicates that the international community supports economic processes with urgency only when socioeconomic factors threaten regional stability.

International Actors and the Reconstruction of Civil Society: Pragmatic Rather than Emancipatory? 
International efforts to develop a liberal civil society in Kosovo have produced hybrid results. The core intentions behind supporting a liberal civil society were to engineer multi-ethnicity as the new defining fabric of Kosovo society and civic identity, to overcome the nationalist confrontationist agendas (United Nations 2000; UNDP 2008), replacing them with a liberal constitutional framework and an active civil society. As early as 2000, UNMIK established the legal and institutional structures for building civil society, which included "the promotion of public participation in governance, fulfilment of civic responsibilities, minority reintegration and post-conflict reconciliation" (United Nations 2000). While this aspect of liberal peace contains some emancipatory aspects, it has not been implemented in practice. After the formation of first local institutions in Kosovo, UNMIK excluded civil society from political processes in Kosovo. Paradoxically, the space for inter-ethnic interaction was created only through incentivising the returnees and making economic aid conditional on improving ethnic relations (Collaborative for Development Action 2006). As a result of these dynamics, local political elites in Kosovo accused civil society groups of working against the national interest and serving foreign agendas (KIPRED 2010). The OSCE and United Nations encouraged civil society's involvement in law-making only after the de facto end of their executive mandates, whereby they tried to compensate for their marginal role in postindependence developments indirectly through local civil society advocacy groups (OSCE 2011). The EU-facilitated dialogue between Kosovo and Serbia that started in 2011 has operated on the premise of top-down and technocratic peace, which has mainly involved senior experts and government officials (Hopkins 2014). It has largely ignored beneficiary communities, and civil society groups in both countries. The technical and high-level political dialogue between Kosovo and Serbia signifies the EU's focus on normalising and improving peace at the regional, state and institutional levels rather than at the everyday and the individual levels (Hopkins 2014). The on-going talks between Kosovo and Serbia could ease political relations but prospects remain shallow for social reconciliation unless the talks ultimately include localized and bottom-up processes of dealing with the past, where the victims are recognized and civically commemorated, bodies of missing persons identified, and survivors are materially compensated.

However, these externally imposed technologies of peacebuilding have not increased significantly inter-ethnic cooperation, but rather represent sources of latent ethnic confrontation (Collaborative for Development Action 2006). While peacebuilding efforts have focused on working with more easily accessible groups, such as young people and women, peacebuilding in Kosovo has failed to engage with the most sensitive groups and has 
done little to support the families of missing persons because of their strong criticism against the delays in resolving the fate of hundreds missing persons (Centre for Research, Documentation and Publication 2012). In other words, the international community disregarded the most basic aspects of everyday peace, which are needs-based encounters of both an ideational and material nature that may have little in common with peace perceived as multi-ethnicity, tolerance, and inter-ethnic reconciliation. The significant reduction of donor funds for local NGOs after Kosovo's independence resulted in the professionalization of services provided by NGOs and their operations in joint networks, while many other grassroots organizations ceased operating due to unsustainable funds. The European Union currently remains the main donor of local NGOs in Kosovo, for which it has set funding priorities mainly related to European Union integration rather than responding to the local needs (TACSO 2014). After independence, the NGO sector was more oriented towards criticising government performance than on working for the normalisation of inter-ethnic relations and strengthening peace and reconciliation in ethnically mixed regions. ${ }^{1}$ A shortage of donor support pushed many civil society activists to join political parties, which did not result in improving the government's performance but further damaged the reputation of the civil society sector in Kosovo (UNDP 2012, 13).

In response to the lack of critical citizenry and its suppression by donor-oriented civil society groups in addition to the politics of liberal peacebuilders, critical civil society groups gradually started to emerge, who defied the imposition of liberal peace. Other groups also operated in the grey zones, utilizing donor funding while building a repertoire of critical activism and critical pedagogy towards authorities. For example, Lëvizja Vetëvendosje (Movement for Self-Determination) was, for several years, the leading populist movement operating outside the liberal peace space in Kosovo given its commitment to criticising and defying the imposed peace in Kosovo as well as the misconduct of local institutions. It demanded broader participatory democracy and social justice, defied the neo-liberal economic system, struggled for people's right to self-determination, and rejected the multi-ethnicity project in Kosovo (Kurti 2011). While the movement partially represented a new emancipatory politics in Kosovo, their exclusionary practices and nationalist discourse did not attract great internal and external support. Vetëvendosje's conception of peace is not based upon the grounds of empathy, tolerance, concession, and autonomy, but on majoritarian power, identity domination, and a statist/realist conception of freedom, rights, justice, and peace. On the positive side, they offered a vision of social emancipation, fair justice, and

\footnotetext{
${ }^{1}$ Personal interview, civil society activist. Pristina, May 22, 2014.
} 
effective governance and the possibility of escaping the dependency on international governance, but one that is heavily constrained by self-determination and nationalist claims.

Beyond the institutional framework of peacebuilding and local resistance, there is some evidence of local peacebuilding led by community-based civil society groups. The government agenda in Kosovo has not prioritized local peacebuilding, and together with the international community, focused rather on stability, power consolidation, and regional peace. Ethnic politics can be antagonistic for reconciliation, so these local civil society groups often seek to distance themselves from such aspects and work on resolving everyday socioeconomic challenges. These groups have utilized local knowledge, capacity, and legitimacy to modify externally set normative frameworks with the sole purpose of addressing ethnic distrust and structural violence, overcoming the past, and reducing horizontal inequalities. These local peacebuilding initiatives have the potential to develop positive local agency, overcome the negative agency of local resistance groups, and overcome the flaws and limitations of top-down, institutional, and power-driven peace in Kosovo.

Liberal peace missions in Kosovo also devoted considerable attention to the rule of law and justice sector. The presence of multiple sources of applicable law, and the presence of local and international judges, prosecutors, and police officers did not create an effective rule of law in Kosovo (King and Mason 2006). In response to the limited role of international transitional justice in Kosovo, a number of local and regional civil society initiatives have emerged which seek to mobilise bottom-up groups to search and document past human rights abuses, engage with the victims on all sides of the conflict, and seek recognition and support for victims of past suffering beyond ethno-nationalist politics (Visoka 2016b). However, sceptics fear that these initiatives are embedded in the current global transitional justice ideology, which seeks more political stability, compensation for international failures than meaningful, localized, and situational forms of dealing with the past and bringing justice and recognition to the victims (Di Lellio and McCurn 2013).

Overall, the liberal peace missions in Kosovo have not managed to produce a sustainable and emancipatory social contract, where the people's needs and will are at the centre and the democratic principles of socio-economic and ethnic equality are incorporated within state practices in order to attempt to meet their claims. The new state institutions have enshrined Weberian and neoliberal attributes of governance, combined with the local culture of informal governance based on clans and regional allegiances (Skendaj 2014). They have been driven by compromises with geo-economic, regional, and local structural conditions, rather than emancipatory claims. This type of liberal statebuilding has not promoted equality 
and justice, but rather expanded the inequality gap and increased social discrimination. It has enhanced rather than replaced the oligarchical nature of politics. So far, any movement centred on the discourse of liberation and emancipation has ended up capturing power and reproducing old systems of power. Civil society, which is considered a pioneer of civic pluralism and social emancipation, has not been able to promote emancipatory politics in Kosovo due to their donor-driven conduct and detachment from communities. They have not managed to strengthen social trust within and between different communities in Kosovo. At best, they have tried to act as watchdogs over the government, and to some extent over donors and the EU.

\section{Envisaging a More Emancipatory Peace in Kosovo}

If transformation has historically been linked with Enlightenment rationalism, scientific discovery, various forms of elite domination, capitalism, as well as the improvement of rights pertaining to life, work, welfare, and sustainable economies and ecologies, with an approximation of material equality, this provides a clear direction for the evaluation of the existing 'peace' in Kosovo as well as its improvement. Indeed, much of this seems to be at the heart of Kosovan claims for a more emancipatory form of politics and peace: autonomy, respect for identity, legitimate authority, pluralism, representation, accommodation of the socio-economic needs of the population, as well as the historical and distributive justice claims of the different ethnic and minority communities.

As the existing ideologies and ethno-nationalist agendas in Kosovo are not conducive to emancipatory peace, there are other alternative local voices which seek to search for such a vision outside the present political order as well as beyond existing external blueprints for peace (as liberal or neoliberal forms of peace also appear to be inadequate), the state, and the economy. Building on the authors' long-term observation and consultation with local and international actors, we argue that the space for an emancipatory peace could emerge only in a conciliatory vision of peace and state between different internal and external forces, differently constituted rights and claims, and needs. This is not a utopian view of peace, or another interventionary framework. It is rather an attempt to outline an emancipatory framework of peace as non-domination rooted in local peace-enabling agency, drawing on the perspectives and approaches of local peace actors, and pointing to how international actors might facilitate this framework. It is a tentative sketch and alternative account of how a local emancipatory peace could emerge in Kosovo, as well as an attempt to operationalise further empirically post-liberal forms of peace. 
In the remainder of this paper, we highlight some of the key aspects of an emancipatory peace in Kosovo. While we focus on exploring areas where transformation could take place, the micro-details of how such emancipatory change would materialise remains certainly in the domain of local practitioners and peacebuilders. We are not making here a prescriptive statement, rather an outline of outstanding and divisive issues which seem to be sources of tension, whose transformation could lead to a more sustainable peace. The nature of emancipatory justice would require justice for past crimes but also depoliticising and de-ethnicizing it in the future. Ethnic relations could recover only through a multi-layered dialogue making space for state and individuals to take individual and collective responsibility for past suffering and develop forward-looking conciliatory narratives. As the sociology of conflict is related to state formation in Kosovo, questions of sovereignty and statehood might be inevitable to enable self-governance, domestic and regional peace, and integration into the European Union and global society. To enable social emancipation, the nature of governance would need to promote local representation, popular consent, rather than authoritarian and external rule. This should go beyond the facades of local ownership that is often cooped by ethnic elites to include local peace infrastructure. Material constraints would inevitably require more external subvention (a structural issue that would need to be solved with more international enablement of locally legitimate authority and economic assistance). The security apparatus would need to be reformed to put people's security before state security. Often, human security is made redundant when exploited by local elites for monoethnic security and external actors for stabilisation purposes. Finally, the economy would need to promote local production and provide welfare (requiring both protectionism and aid), while also remaining connected to the global economy in a positive manner. Such views tend to be propagated amongst a small group of commentators, activists, NGOs, and policymakers who reject national interest, ethno-nationalism, see the state's role mainly as delivering social justice and law, and think in terms of a more durable and sustainable form of peace.

One of the crucial sources of disagreement in Kosovo is the persistence of different visions of peace, state, governance and development by internal ethnic groups and external involved states. These different conceptions are rooted in ontologically distinct histories, narratives, experiences, interests, and needs, thereby combining rational and emotional, collective and individual perspectives. Whereas Kosovo Albanians relate peace to freedom, statehood and majoritarian rule, Kosovo Serbs relate it more with ethnic security and 
separation. ${ }^{2}$ Other non-dominant minorities, such as Roma, Ashkali, Egyptians, Turks and Bosniaks view peace more in relation to security and equality. ${ }^{3}$ The US and European states relate peace to order, stability, and statebuilding, while non-western states perceive peace more in relation to non-interference, and peaceful resolution of disputes. So, prospects for a emancipatory peace in Kosovo require a mediation or conglomeration of these various conceptions. On this basis, the space for emancipatory peace would require developing a pluralist and civic identity beyond divisive ethno-nationalist politics, as well as alleviating structural violence and inequality by the majoritarian groups. ${ }^{4}$ Local civil society groups can play a crucial role in promoting civic identity. The dominant international role needs to be replaced with other more facilitative forms of engagement that enable local agency to promote and sustain a positive and emancipatory peace. Yet at the same time, the risk of violence and various predatory forms of power require a firmer security role in the absence of a state able to achieve such goals.

To improve the quality of peace, the conciliatory nature of justice would require dealing with the past and accountability for war crimes not only through international and institutional mechanisms part of transitional justice, but also through community-based interaction, dialogue, and reconciliation. ${ }^{5}$ Inter-community truth seeking and apologies for past violence, is crucial to open up the space for gradual reconciliation as part of a emancipatory conception of peace (Visoka 2016c). Mono-ethnic parties in Kosovo have sidelined local civil society groups who are more promote to dialogue and inter-ethnic compromise than the ethno-nationalist elites. Civic initiatives can play a crucial role in shaping a bottom-up reconciliation agenda. In addition, the administration of justice should not continue to be divided along ethnic lines, and the confidence-building measures should come through an interactive dialogue between different communities employed within the Civil Service. Furthermore, regional dimensions of such justice frameworks would also have to be addressed, possibly indicating a wider regional process of institution-building. Reconciliation is closely related to injustice, but also involves recognizing past suffering and overcoming past divisions, such as apologies for past crimes, resolving the fate of missing persons and post-war abductions, as well as resolving property and land disputes. ${ }^{6}$ Under these conditions, an emancipatory policy would require initiating a process of official

\footnotetext{
${ }^{2}$ Focus group discussion, Kosovo-Albanian student 1; Pristina, May 23, 2014; Focus group discussion, Kosovo-Serb civil society activist 2, Pristina, April 20, 2015.

${ }^{3}$ Personal email communication, Kosovo Roma civil society activist, October 20, 2014.

${ }^{4}$ Focus group discussion, Kosovo-Albanian student 1, Pristina May 23, 2014; Focus group discussion, Kosovo-Serb civil society activist 3, Pristina, April 20, 2015.

${ }^{5}$ Personal interview, Kosovo-Albanian transitional justice activist, Pristina, January 28, 2015.

${ }^{6}$ Personal interview, Local Kosovo-Serb civil society activist, Pristina May 23, 2014.
} 
apologies for war crimes in Kosovo, launch a multi-layered truth-seeking and truth-document process, foster the return of refugees, and resolve all outstanding individual property-related disputes. There are some existing efforts in Kosovo undertaken by civil society groups (such as the Humanitarian Law Centre, Youth Initiative for Human Rights, and the Centre for Research, Documentation, and Publication), but they lack domestic and international political support to resolve these issues at the policy level and do not engage sufficiently with the victim community to ensure bottom-up legitimacy (Centre for Research, Documentation and Publication 2012).

Within the context of the Kosovo conflict, an emancipatory peace is closely linked with the statehood-related questions about sovereignty, governance, security and the economy. Despite the fact that statehood and self-determination are contentious issues, as discussed earlier in this article, the resolution of statehood in the case of Kosovo it is inevitable as the majority of population affiliates peace with statehood. The conflict in Kosovo was primarily a sovereignty-related conflict, and this struggle now continues through peaceful means. While Albanians in Kosovo demand full independence and full diplomatic recognition, Serbia rejects Kosovo's independence and the Serb community in Kosovo is in favour of shared sovereignty or autonomy within Serbia. ${ }^{7}$ Therefore, searching for an emancipatory peace requires reconciling divisions on the question of Kosovo's statehood, as well as the risks of nationalism. Under these conditions, an acceptable peace would involve Serbia recognizing Kosovo's independence and enabling Kosovo's United Nations membership, in return for regional autonomy for Serbs in the north of Kosovo (International Crisis Group 2011). These dynamics are emerging within the existing EU-facilitated technical and political dialogue between Kosovo and Serbia, but alternative conciliatory options are available similar to the model of the two Germanys, which involved the normalization of relations without formal recognition and the removal of blockages for Kosovo and Serbia to both join the European Union, and for Kosovo to join the United Nations. However, a more emancipatory peace settlement and form of state would have to be connected to regional and international reform, as the limitations of European Union governance and the United Nations system, as well as the nature of global capital, have partly provided the conditions for the current settlement and state. Any conception of emancipatory peace that does not connect the local and international risks generating utopian visions of peace.

Another issue crucial for emancipatory peace is the politics of governance in Kosovo and the need to overcome its ethno-nationalist nature. Kosovo Albanians generally support

\footnotetext{
${ }^{7}$ Focus group discussion, Kosovo-Albanian student 2, Pristina, May 23, 2014.
} 
democratic governance, but there are tendencies to exploit their demographic majority within institutions. On the other hand, Serbs support extensive decentralisation, and ethnic quotas for public institutions, while other non-dominant communities favour fair and proportional representation in local and central government. ${ }^{8}$ The existing power-sharing governance structures both at the local and central government in Kosovo have reproduced mainly ethnonationalist politics and have impeded civic politics from emerging. So, emancipatory governance in Kosovo should overcome ethno-nationalist politics and give way to a social and participatory democracy, where the role of external actors is only facilitative and not aimed at micro-managing domestic politics. This progressive vision would work only if postnationalist politics govern Kosovo, Serbia and the broader region and if the European Union provides strong economic incentives to foster cooperation and inter-dependency, as well as supporting local peace initiatives that are crucial for community-based dispute avoidance. Unfortunately, this very significant aspect of the Kosovo quagmire requires regional and global structural reform in political and economic realms before an emancipatory solution can be introduced to Kosovo. However, in the immediate future, it seems that only internal struggle among ethnic groups and competition for electoral support can generate change that is more supportive of social welfare, inter-ethnic peace, and enhancement of state-society relations.

Related to governance, security is another contested issue that is instrumental in the formation of a local emancipatory peace. A sensitive on-going question in Kosovo relates to the prospects for an integrated army and its role after the withdrawal of NATO peacekeepers from the country. Kosovo Albanians insist on having an army and reject the presence of any Serb security presence in the north of Kosovo (KohaNet 2014). On the other hand, the Serb community fears such security changes and, if Kosovo must have its own armed forces, they demand that it would have limited authority and no presence in the north of Kosovo (BIRN 2014). Non-dominant communities are mainly concerned with human security. There is also division amongst the international community as to whether Kosovo should have an armed forces and what role it might have. A conciliatory alternative is to establish security institutions with limited powers, a small active force, and under civilian control, which is also open and inclusive to minorities. Kosovo is currently developing its armed forces, but this process of securitization may increase insecurity in Kosovo and the region, ${ }^{9}$ rather than complete demilitarisation across the region. Liberal peace interventions have supported

\footnotetext{
${ }^{8}$ Personal email communication, Kosovo Roma civil society activist, Pristina, October 20, 2014.

${ }^{9}$ Personal email communication, international humanitarian worker, Pristina, January 28, 2015.
} 


\section{After Liberal Peace?}

militarism in post-conflict societies to accommodate ex-combatants and to secure some degree of order after their exit.

Finally, an emancipatory peace requires material foundations, which challenges the neo-liberal economic model, focussing on universal employment, promoting local production, and supporting social welfare. For this to take place, economic activity and the politics of employment should overcome ethnic preferences and provide space for equal and fair chances for professional employment. Structural support, rather than conditionality, from external donors would be required. To enhance local legitimacy in political authority, local actors, working towards an inclusive, emancipatory, and positive hybrid peace, would signal to external actors how local power structures perpetuating conflict could be bridged or mitigated, and what material and rights aspects of the conflict could be resolved or transformed with outside help. International donors provide socio-economic support only when such a move is essential for maintaining political and social stability. They would also work out how these would be reconciled with international norms and law. Sovereignty in peace formation would lie with democratic government, not outside bureaucrats, requiring some protection from global capital and regional geopolitics. However, it would not be territorial, but would rather require a regional dimension of integration. While some of these aspects of emancipatory peace might resonate with liberal peace - at least in theory and to certain extent what was desired in Kosovo but not achieved - the quintessential difference between liberal peace and the post-liberal peace propagated here is the displacement of agency from state structures and ethnic elites, as well as international actors, to individuals, networks, groups, and the bottom-up infrastructure for peace.

Key to emancipatory peace in Kosovo is a critical citizenry, which involves the personal transformation of the people living in post-conflict societies who question the existing ethno-nationalist, top-down, elite-driven, and externally-controlled politics (Visoka 2017). According to the evidence outlined above, they would aim at rejuvenating local democracy as well as egalitarian principles of equality, justice and fairness. These are generally found to be inadequate in both the current environment and in the model proposed by internationals according to this community. If a more emancipatory peace in Kosovo is to take root it should be centred on peoples' emancipation from the existing local political order, and a reform of the states in the region. It would also require, after a long-term presence of external actors, a departure for dependency on external forces. So, at the centre of a more emancipatory politics should be placed the development of a critical pedagogy for an active citizenry, which is directed towards a revised form of social contract, allied to global reforms 
to mitigate inequality and the negative effects of globalisation. This also entails the emergence of local civil society groups who are not primarily attuned to implementing external donor agendas, but are genuine local change-makers, promoter of local peace, and representatives of emancipatory virtues.

One key aspect of this critical pedagogy is to learn to act as a 'powerful citizen' (regardless of the material and social conditions) by knowing, respecting and protecting human rights and needs, in addition to positive social values suited to local context and meaning. This has never been supported in practice by liberal peacebuilders as they have prioritized external interests, and by working with ethnic elites have unintentionally suppressed local pro-peace agency. The material and social conditions provided by the donorsponsored statebuilding process are not conducive to citizen experiments with pluralism. Instead, they encourage competition, asset-stripping, and economic practices aimed at elite profit rather than social good. For instance, European Union integration conditionality has constantly narrowed political and socio-economic freedoms in Kosovo, while enabling local elites to dilute responsibility for the absence of progress in Kosovo.

While the prospects for peace formation are more likely when local perspectives, needs and interests are taken into account, the local habitus alongside different cultural practices are often sources that generate and reproduce violence and social turbulence leading thus to negative hybrid forms of governance. Therefore, emancipatory peace should replace them with a contextually grounded re-interpretation of culture based on global principles of human rights, justice, fairness, well-being, and empathy with difference. For example, gender relations would need to be reformed in order to enable women to gain the same social, economic, and political status, and avoid structural subalternity rooted in local culture, such as the denial of inheritance and social discrimination. Emancipatory peace would emerge only when the established cultures of silence, disinterest, negligence, and ignorance are replaced with constructive criticality towards cultural regimes of practices, where nobody remains hostage to harmful, destructive, violent, discriminatory, and exclusionary traditional practices and values.

A more emancipatory peace in Kosovo would be pluralist across ethnicity, language, and religion. In order to address structural inequalities caused by past discrimination, it would require the state to actively intervene and rebalance, facilitated at the regional and international level. For the state to do so, in the light of material inequality at the regional and global levels, donors, the EU, other regional and global actors would also need to ensure a level playing field between their citizens and those of Kosovo, in terms of rights, access to 
opportunities, and free movement of people, capital, and services. Clearly, little of this has thus far been achieved at the regional or international level, though some steps have been taken. The securitisation of European Union borders and limited regional connectivity has negatively affected the emergence of post-national identity in Kosovo. At the local level, an emancipatory peace would require changing citizens' attitudes and perceptions towards state, community and activism. State-society relations would be reshuffled in the direction of representing needs, interests and rights at the local and national levels. Critical citizenry requires making conditional the consent, agency, and willingness to obey the law and taking on obligations in exchange for decent representation of needs, interests, and rights. This would be essential to establish a proper social contract between the citizens and the state. Political representatives should not take their political authority for granted: instead they should see it as an obligation in service of the general population. To enable this shift in statesociety relations, a critical citizenship requires cultivating a culture of community activism, discussion of common problems with neighbours and finding ways of mobilizing the community in order to maintain such checks and balances.

From a local needs-based perspective, an everyday peace would look as follows: a safe and secure community, autonomous but yet integrated into regional and international order; basic functioning public services, accessible education, healthcare; and jobs to enable family security and development. While this is more conducive to mono-ethnic and stable communities, in mixed communities an everyday peace adds layers of good neighbourliness and conflict avoidance with members of other ethnic and religious communities (Mac Ginty 2014). This would also mean changing the existing relations of labour forces, re-energizing trade unions, and empowering workers' rights. Cross-community cooperation would be possible only if the nationalist political discourse is transformed and a new discourse of common civic identity emerges in the light of the European integration process.

\section{Conclusion}

An important debate during the liberal peace era was over the nature of emancipation in a post-socialist world. One of the critical arguments about the liberal peace was that it had abandoned direct emancipation in its focus on security, institutions and law, bureaucracy, and economic development, thus also downgrading reconciliation and broad forms of justice as a goal of peacebuilding. From this perspective, the role of the state was to modernize and provide a level playing field in which citizens could transcend ethnic or religious difference. The Kosovo case sheds some light on the limitations of this recent approach, as well as what a 
more emancipatory peace framework may look like from the perspective of those who have experienced this process at the "sharp end," having had the experience of liberal peacebuilding and neoliberal statebuilding since 1999. It allows us to chart citizens' responses to the neoliberal state model, which sees inequality as the engine of social change and economic development, as well as to evaluate its overall achievements according to development indices. The latter shows a moderate improvement, the former indicates much ambivalence. As legitimacy and development are crucial to a state's viability, this is concerning. In the realm of security, matters are much improved, though inter-ethnic relations remain dangerously fragile. Local perspectives in Kosovo show that post-liberal forms of peace are needed in order to take into account local claims, often incompatible and conflicting among ethnic groups, and from the bottom up encourage dialogue, enable spaces for coexistence and transformation, whilst reducing external and top-down imposition that only antagonise local population and legitimate ethno-nationalist elites.

What happens if the peace settlement is negative and hybrid in form? If the state is not socially legitimate but instead a vehicle for power relations? If the peace settlement and the state are resistant to a positive hybrid form emerging from the mediated claims of resident and related populations? As indicated earlier, at this historical stage of the development of peace, the state, regional organizations, and the international system, the above discussion offers a picture of a hybrid of liberal peace, Kosovan politics, and regional relations, ideally reconfigured in order to provide citizens with the prospect of much improved lives, and the social, political, economic, and security in order to achieve a stable local and regional order. This could be said to be a positive form of hybrid peace, as opposed to the current negative form. In reality, efforts to build a liberal peace in Kosovo have produced negative hybrid outcomes, partly geopolitical, partly liberal, partly oligarchic and nationalist. Both the international community and ethnic elites have created a flawed democracy and oligarchical capitalism with weak local legitimacy. The primacy of territorial stability and regional order has unintentionally suppressed the emergence of a new social contract that would promote an emancipatory peace, pluralist citizenry, and social justice. Ethnic power-sharing has entrenched nationalist groups and permitted the formation of an authoritarian culture, which has undermined reconciliation and contributes to the re-territorialisation of power and entrenched ethnic divisions. Oligarchical capitalism through a neo-liberal economic regime has brewed corruption, increased poverty and distorted social wellbeing. This negative hybrid peace and contested state is not capable of meetings its citizens' claims, nor capable of 
matching the requirements for European Union integration, or sufficiently supported to contribute to international society.

While an emancipatory impetus is traceable in certain local civil society initiatives, overcoming the contradictions of the hybrid social contract in Kosovo requires reconciling a divisive conception of state, and peace, and promoting a pluralist, locally generated civic identity. It would offer the power of attraction of future progress for all, meaning that it is widely supported by society and therefore can construct legitimate authority. This locally grounded emancipatory peace would require changing the character of the existing state in Kosovo. Ironically, failed statebuilding has provided some space for these approaches to crystallise in theory and civil society praxis, but in both they are still marginal when compared to elite power relations within the state, across the region, and when compared to the system of global governance embedded within Kosovo. However, even when local progressive actors have their way, they find (as they themselves point out) that a lack of consensus and stability in the understanding of peace at the international level, as well as a lack of political will, undermines their attempts to inculcate pluralism, liberalism, and social justice.

\section{References}

Anderson, Alex. 2010. State of Constriction: Governance and Freedom of Expression. Pristina: Youth Initiative for Human Rights.

BAliBAR, ETIENNE. 2002. Politics and the Other Scene. London: Verso.

BALKAN INVESTIGATIVE REPORTING NETWORK (BIRN). 2014. "Serbia Seeks Guarantees about Kosovo Army." Balkan Insight. Accessed March 6, 2016. http://www.balkaninsight.com/en/article/serbia-opposes-kosovo-future-armed-forces.

BoOTH, Ken. 1991. "Security and Emancipation.” Review of International Studies 17: 313326.

BRINK, DAVID O. 2013. Mill's Progressive Principles. Oxford: Oxford University Press.

Capussela, Andrea L. 2015. State-Building in Kosovo: Democracy, Corruption and the EU in the Balkans. London: I.B. Tauris.

Collaborative for DeVelopment ACtion. 2006. Has Peacebuilding Made a Difference in Kosovo? A Study of the Effectiveness of Peacebuilding in Preventing Violence: Lessons Learned from the March 2004 Riots in Kosovo. Pristina: CDA and CARE International. 
Central EleCtion Commission (2014) ‘2014 Election Results’. Pristina: Central Election Commission. Accessed July 19, 2016. http://www.kqzks.org/Uploads/Documents/Rezultatet\%20sipas\%20Subjeketeve\%20\%2020140526\%20Party\%20Results\%20-\%20Kosovo\%20Level_jywcwsfyts.pdf.

CHANDLER, DAVID. 2010. International Statebuilding: The Rise of Post-Liberal Governance. Abington: Routledge.

Centre for Research, Documentation And Publication. 2012. "Needs Assessment Victims of Conflict in Kosovo: Time to Stop and Listen." Pristina: Centre for Research, Documentation and Publication. Accessed July 19, 2016. http://crdpks.org/wp-content/uploads/2013/01/20131210-web-crdp-publikimi.pdf.

Di LELlio, ANNA, AND CAITLIN MCCURN. 2013. "Engineering Grassroots Transitional Justice in the Balkans: The Case of Kosovo." East European Politics \& Societies 27: $129-148$

DOBSON, ANDREW. 2014. Listening for Democracy: Recognition, Representation, Reconciliation. Oxford: Oxford University Press.

DoYLe, Michael W. 2012. Liberal Peace: Selected Essays. Abington: Routledge.

EUROPEAN COMMISSION. 2015. "Kosovo Progress Report, SWD(2015) 2015 Final." Brussels, November 10. Accessed March 15, 2016. http://ec.europa.eu/enlargement/pdf/key_documents/2015/20151110_report_kosovo.p df.

FORUM 2015. 2011. "The Weakest Link of Kosovo's Democracy." Pristina: Kosovo Foundation for Open Society. Accessed March 19, 2016. http://kfos.org/wpcontent/uploads/2011/10/the-weakest-link.pdf.

FORUM FOR DEMOCRATIC INITIATIVES. 2009. "Diaspora as a driving force for development in Kosovo: Myth or Reality." Gjakova: Forum for Democratic Initiatives. Accessed July 19 , 2016. https://www.eda.admin.ch/content/dam/deza/en/documents/laender/resource183043_EN.pdf.

Giddens, Anthony. 1991. The Consequences of Modernity. Cambridge: Polity Press.

HEHIR, AIDAN, ED. 2010. Kosovo, Intervention and Statebuilding: The International Community and the Transition to Independence. London: Routledge.

HopKIns, VALERIE. 2014. "Big Deal, Civilized Monotony? Civilian Oversight of KosovoSerbia Agreement Implementation.” Pristina: BIRN Kosovo. March 18, 2016. http://www.balkaninsight.com/en/file/show/BIG\%20DEAL\%20FINAL\%20ENG.pdf. 
INTERNATIONAL CRISIS GROUP. 2009. "Serb Integration in Kosovo: Taking the Plunge." Pristina/Brussels: International Crisis Group. Accessed March 18, 2016. http://www.crisisgroup.org/ /media/Files/europe/200_serb_integration_in_kosovo taking_the_plunge.pdf.

-----. 2010. “The Rule of Law in Independent Kosovo.” Pristina/Brussels: International Crisis $\begin{array}{llll}\text { Group. } & \text { Accessed } & \text { March } & 18,\end{array}$ http://www.crisisgroup.org/ /media/Files/europe/balkans/kosovo/204\%20The\%20rul e\%20of\%20Law\%20in\%20Independent\%20Kosovo.pdf.

-----. 2011. "North Kosovo: Dual Sovereignty in Practice.” Pristina/Brussels: International $\begin{array}{lllll}\text { Crisis } & \text { Group. } & \text { Accessed } & \text { March }\end{array}$ http://www.crisisgroup.org/ /media/Files/europe/balkans/kosovo/211\%20North\%20 Kosovo\%20---\%20Dual\%20Sovereignty\%20in\%20Practice.

JARSTAD, ANNA K., AND Timothy D. SISK, EDS. 2008. From War to Democracy: Dilemmas of Peacebuilding. Cambridge: Cambridge University Press.

Jarstad, AnNa K., AND Roberto Belloni. 2012. "Introducing Hybrid Peace Governance: Impact and Prospects of Liberal Peacebuilding." Global Governance 18: 1-66.

Knudsen, Rita Augestad. 2013. "Privatisation in Kosoco: 'Liberal Peace' in Practice" Journal of Intervention and Statebuilding 7: 287-307.

Kosovo Agency of Statistics (KAS). 2013. Results of the Kosovo 2013 Labour Force Survey. Pristina: Kosovo Agency of Statistics.

King, IAn, And Whit Mason. 2006. Peace at Any Price: How the World Failed Kosovo. London: Hurst \& Co.

KoHANET. 2014. "Kosova behet me ushtri [Kosovo becomes with Army].” Accessed March 4, 2015. http://koha.net/?id=27\&l=1818/.

Kosovar Institute for Policy ReSEARCH AND DEVElopment (KIPRED). 2010. Review of Decentralization - Functioning of Serb Majority Municipalities. Policy Brief 2010/5. Pristina: Kosovar Institute for Policy Research and Development.

------ 2012. Strengthening the Statehood of Kosovo through the Democratization of Political Parties. Policy Paper Series 2012/04. Pristina: Kosovar Institute for Policy Research and Development.

Kostovicova, DenisA. 2013. “Airing Crimes, Marginalizing Victims: Political Expectations and Transitional Justice in Kosovo." In The Milosevic Trial: An Autopsy, edited by Timothy W. Waters, 249-259. New York: Oxford University Press. 
KURTI, ALBIN. 2011. "JISB Interview: Kosova in Dependence: From Stability of Crisis to the Crisis of Stability." Journal of Intervention and Statebuilding 5: 89-97.

Linklater, ANDREw. 1997. "The transformation of Political Community: E. H. Carr, Critical Theory and International Relations." Review of International Studies 23: 321338.

1998. The Transformation of Political Community. Cambridge: Polity Press.

LOCKE, JOHN. 1988 [1689]. Two Treatises of Government. Cambridge: Cambridge University Press.

MAC GINTY, Roger. 2014. "Everyday Peace: Bottom-up and Local Agency in Conflictaffected Societies." Security Dialogue 46: 548-564.

Malazogu, LeON, Filip EJdus, Milan Mič, AND Tomasz ŻoRnaCZuK. 2014. Integration or Isolation? Northern Kosovo in 2014 Electoral Limbo. Bratislava: Central European $\begin{array}{lllll}\text { Policy Institute. } & \text { Accessed July }\end{array}$ http://www.cepolicy.org/sites/cepolicy.org/files/attachments/cepi__integration_or_isolation.pdf.

Newman, EdWard, Roland Paris, AND Oliver P. Richmond. 2009. New Perspectives on Liberal Peacebuilding. Tokyo: UNU Press.

NorRIS, PIPA. 2011. Democratic Deficit: Critical Citizens Revised. Cambridge: Cambridge University Press.

OMBUDSPERSON IN KoSOVO. 2012. Eleventh Annual Report 2011. Pristina: Ombudsperson in Kosovo.

ORGANIZATION FOR SECURITY AND COOPERATION IN EUROPE (OSCE). 2009. Communities Rights Assessment Report. Pristina: Organization for Security and Cooperation in Europe.

-----. 2010. Kosovo's War Crimes Trials: An Assessment Ten Years On 1999-2009. Pristina: Organization for Security and Cooperation in Europe.

-----. 2011. Reference Book for Civil Society Organizations: Participation in the Legislative, Oversight, and Budget Processes of the Assembly of Kosovo. Pristina: Organization for Security and Cooperation in Europe.

PARIS, ROLAND. 2010. "Saving Liberal Peacebuilding." Review of International Studies 36: $337-65$.

PHILlIPS, DAVID. 2012. Liberating Kosovo: Coercive Diplomacy and U.S. Intervention. Cambridge, MA: The MIT Press. 
RADIN, ANDREW. 2014. "Towards the Rule of Law in Kosovo: EULEX Should Go." Nationalities Papers 42: 181-94.

RAWLS, JoHn. 1971. A Theory of Justice. Cambridge, MA: Harvard University Press.

RICHMOND, OLIVER P. 2005. The Transformation of Peace. Basingstoke: Palgrave Macmillan.

-----. 2008. Peace in International Relations. Abington: Routledge.

-----. 2009. "A Post-liberal Peace: Eirenism and the Everyday.” Review of International Studies 35: 557-80.

-----. 2011. A Post-Liberal Peace. London: Routledge.

-----. 2014. Failed Statebuilding. New Haven, CT: Yale University Press.

-----. 2015. "The Dilemmas of a Hybrid Peace: Negative or Positive?" Cooperation and Conflict 50: 50-68.

-----, AND SANDRA PogodDA, EDS. 2016. Post-Liberal Peace Transitions. Edinburgh: Edinburgh University Press.

RORTY, RICHARD. 1989. Contingency, Irony, and Solidarity. Cambridge: Cambridge University Press.

RUECKer, JOACHIM. 2011. Standards and Status: How Kosovo Became Independent. Munich: Verlag Otto Sagner.

SKENDAJ, ElTON. 2014. Creating Kosovo: International Oversight and the Making of Ethical Institutions. Ithaca, NY: Cornell University Press.

SHAPCOTT, RICHARD. 2011. Justice, Community, and Dialogue in International Relations. Cambridge: Cambridge University Press.

Susen, Simon. 2015. The 'Postmodern Turn' in the Social Sciences. Basingstoke: Palgrave Macmillan.

TadjbaKhsh, Shahrbanu, ED. 2011. Rethinking the Liberal Peace: External Models and Local Alternatives. Abington: Routledge.

TANSEY, OISIN. 2009. Regime-Building: Democratization and International Administration. Oxford: Oxford University Press.

TACSO. 2014. "Civil Society Needs Assessment: Kosovo.” Pristina: Technical Assistance to Civil Society Organisations. Accessed July 19, 2016. http://www.tacso.org/doc/nar_ko2014april.pdf.

TRINDADE, JoshuA. 2008. "Reconciling the Conflict Paradigms: An East Timorese Vision of the Ideal State." In Democratic Governance in Timor-Leste: Reconciling the Local 
and the National, edited by David Mearns, 160-188. Darwin, Australia: Charles Darwin University.

United Nations. 2000. "UNMIK Regulation No. 2000/40 On the Establishment of the Administrative Department for Democratic Governance and Civil Society." UNMIK/REG/2000/40, July 10. Accessed March 25, 2015. http://www.unmikonline.org/regulations/2000/re2000_40.htm.

United Nations DeVelopment Programme (UNDP). 2008. Civil Society and Development in Kosovo. Pristina: United Nations Development Programme.

-----. 2012. Public Pulse Report 3. Pristina: United Nations Development Programme.

-----. 2015. Public Pulse Report 9. Pristina: United Nations Development Programme.

United States (US) DePartment of State. 2010. "Report of Inspection: Embassy Pristina, Kosovo.” Report No. ISP-I-10-38A, March 2010. Accessed July 19, 2016. https://oig.state.gov/system/files/141666.pdf.

VISOKA, GËZIM, AND ADEM BEHA. 2011. "Minority Consultative Bodies in Kosovo: A quest for effective emancipation or elusive participation?" Journal on Ethnopolitics and Minority Issues in Europe 10: 1-30.

VISOKA, GËZIM. 2016a. Peace Figuration after International Intervention: Intentions, Events and Consequences of Liberal Peacebuilding. Abington: Routledge.

------ 2016b. "Peace Multitudes: Liberal Peace, Local Agency, and Peace Formation in Kosovo." In Post-Liberal Peace Transitions, edited by Oliver P. Richmond and Sandra Pogodda, 65-82. Edinburgh: Edinburgh University Press.

------. 2016c. “Arrested Truth: Transitional Justice and the Politics of Remembrance in Kosovo." Journal of Human Rights Practice 8: 62-80.

-----. 2017. Shaping Peace in Kosovo: The Politics of Peacebuilding and Statehood. Basingstoke: Palgrave Macmillan.

XharRa, Jeta. 2015. "Kosovans Risk Perils of Roads, Forests and Criminals in Chase for Better Life in EU." Guardian, February 17. Accessed March 20, 2016. http://www.theguardian.com/world/2015/feb/17/kosovans-risk-perils-of-roadsforests-and-criminals-in-chase-for-better-life-in-eu. 